\title{
Synthesis and Application of Phenyl Nitrone Derivatives as Acidic and Microbial Corrosion Inhibitors
}

\author{
Shijun Chen, ${ }^{1,2}$ Kang Zhao, ${ }^{1}$ and Gang Chen ${ }^{2}$ \\ ${ }^{1}$ Department of Materials Science and Engineering, Xian University of Technology, Xian 710048, China \\ ${ }^{2}$ College of Chemistry and Chemical Engineering, Xian Shiyou University, Xian, Shaanxi 710065, China \\ Correspondence should be addressed to Kang Zhao; 158737534@qq.com and Gang Chen; gangchen@xsyu.edu.cn
}

Received 17 February 2015; Revised 15 April 2015; Accepted 3 June 2015

Academic Editor: Grégory Durand

Copyright (C) 2015 Shijun Chen et al. This is an open access article distributed under the Creative Commons Attribution License, which permits unrestricted use, distribution, and reproduction in any medium, provided the original work is properly cited.

\begin{abstract}
Nitrone has drawn great attention due to its wide applications as a 1,3-dipole in heterocyclic compounds synthesis and the bioactivities. With the special structure, nitrone can also be used as ligand in inorganic chemistry. Based on the current research, the nitrones are anticipated to be effective inhibitors against acidic and microbial corrosion. The aim of this work is to investigate the inhibitory action of nitrones. In this work, a series of phenyl nitrone derivatives (PN) was synthesized and used as acidic and microbial corrosion inhibitors. The results indicate that several compounds show moderate to high inhibition efficiency (IE) in $3 \%$ $\mathrm{HCl}$. Accompanied with HMTA or BOZ, the IEs greatly increase, and the highest efficiency of $98.5 \%$ was obtained by using PN4 + $\mathrm{BOZ}$. Investigation of the antibacterial activity against oilfield microorganism shows that the nitrone derivatives can inhibit SRB, IB, and TGB with moderate to high efficiency under $1,000 \mathrm{mg} / \mathrm{L}$, which makes them potential to be used as bifunctional oilfield chemicals.
\end{abstract}

\section{Introduction}

The nitrone is an $\mathrm{N}$-oxide of an amine, which is a 1,3dipole and is used in 1,3-dipolar cycloadditions and formal $[3+3]$ cycloadditions in the synthesis of many natural products of biological interest with the remarkable region, and stereo selectivity along with efficient incorporation of multiple stereocenters [1]. Many nitrone derivatives are found to possess pharmacological activity and form an essential part of the molecular structure of important drugs [2-4]. Nitrones are generated most often either by the oxidation of hydroxylamines or condensation of aldehyde/ketone and monosubstituted hydroxylamines [5-7]. Recently, some new methods were developed, such as addition reaction of highly reactive allenyl acetates with oximes and a novel BaylisHillman reaction $[8,9]$. Due to the unique moiety, nitrones have been a fascinating and challenging topic for inorganic chemistry as well. It has been reported that some nitrone compounds can form stable complexes with $\mathrm{Cu}(\mathrm{II}), \mathrm{Ni}(\mathrm{II})$, $\mathrm{Co}$ (II), and $\mathrm{Cr}$ (III) ions [10], which is useful during the acidic corrosion inhibition for the inhibitors interacting with the metal, so they may be potential corrosion inhibitors. Some
$\mathrm{N}$-diphenyl nitrones have been used as corrosion inhibitors for mild steel in organic acid media, and they were found to be with moderate to high inhibition in $20 \%$ formic acid/acetic acid under the concentration of 50 to $150 \mathrm{ppm}$ [11]. It should be noticed that, for most corrosion, the microbiologically influenced corrosion (MIC) cannot be avoided especially in oilfield, so it will be an interesting work to develop inhibitors against acidic corrosion and MIC.

These compounds are generally prepared by two main methods: condensation of carbonyl compounds with $\mathrm{N}$ monosubstituted hydroxylamines [12] and oxidation of secondary amines or hydroxylamines [13]. In particular, the oxidative approach provides the most direct and general method for preparing nitrones. Based on the current research, the nitrones are anticipated to be effective inhibitors against acidic and microbial corrosion. The aim of this work is to investigate the inhibitory action of nitrones.

\section{Experimental}

2.1. Materials. The corrosion tests were performed on Q235A steel with a composition (in wt\%) C: 0.20, P: 0.015, Si: 1.45, S: 
0.15, Mn: 0.020, and Fe balance. A small hole of about $3 \mathrm{~mm}$ diameter near the upper edge of the coupons was made to help hold them with cotton cords and suspend them into the corrosive medium. Before all measurements, the steel samples were mechanically abraded with increasing grades of emery papers $(100,600$, and 1000 grit size) to remove rust particles. The treated coupons were then rinsed by petroleum ether, degreased by ethanol, and dried in air. Finally, the coupons were treated through a procedure that consisted of measuring the length, width, thickness, and diameter and kept in moisture-free desiccators before their immersion in experimental solution. The weights of the specimens were noted before immersion.

2.2. Synthesis of Phenyl Nitrone Derivatives. Benzaldehyde derivative ( $1 \mathrm{mmol}), \mathrm{N}$-methylhydroxylamine hydrochloride $(1.1 \mathrm{mmol})$, and $\mathrm{K}_{2} \mathrm{CO}_{3}(5 \mathrm{mmol})$ were mixed in methanol $(50 \mathrm{ml})$. The mixture was refluxed until the disappearance of benzaldehyde derivative, as evidenced by thin-layer chromatography. It was cooled to room temperature and the insoluble residue was filtrated. The solvent was removed in vacuo and the residue was separated by column chromatography ( silica gel, petroleum ether/ethyl acetate $=1-3: 1$ ), giving the target compound. NMR spectra were recorded using a Bruker Drx-400 spectrometer operating at $400 \mathrm{MHz}$ for ${ }^{1} \mathrm{H}$ in $\mathrm{CD}_{3} \mathrm{OD}-\mathrm{CDCl}_{3}$. Mass spectra were recorded on a Micromass Platform spectrometer using a direct-inlet system operating in the electron impact (EI) mode at $75 \mathrm{eV}$.

2.3. Weight Loss Determination. The corrosion tests were performed on Q235A steel with a composition (in wt\%) C: 0.22, P: 0.045, Si: 0.35, S: 0.05, Mn: 1.40, and Fe balance. The electrolyte solution was $1 \mathrm{M} \mathrm{HCl}$, prepared from analytical grade $38 \% \mathrm{HCl}$ and distilled water. All tests have been performed in water solutions and at $333 \pm 0.5^{\circ} \mathrm{C}$ for $5 \mathrm{~h}$. The gravimetric tests were carried out according to the Standard of Petroleum and Natural Gas Industry of China (Evaluation method for behavior of corrosion inhibitor for produced water of oilfield, SY/T5273-2000) with a few modifications. Each test was done with three specimens at the same time to give reproducible results.

2.4. Microbiological Monitoring. Viable counts of sulfate reducing bacteria (SRB), iron bacteria (IB), and total general bacteria (TGB) were determined with the "most probable number" method (China Standard of Petroleum and Natural Gas Industry, the national method of the bactericidal agent's performance, SY/T 5890-1993). The produced water containing the three kinds of bacteria was gathered from Zichang Oilfield Factory, Yanchang Oilfield.

\section{Results and Discussion}

3.1. Synthesis. Phenyl nitrone derivatives were synthesized as shown in Scheme 1. The different substitutes are listed in Table 1. The NMR, MS, yield, and the name of the synthesized compounds were also included in Table 1. From the results, it can be found that the phenyl nitrone derivatives are all in

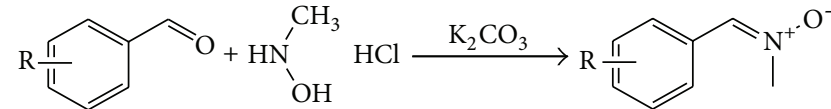

Scheme 1: Synthesis of phenyl nitrone derivatives.

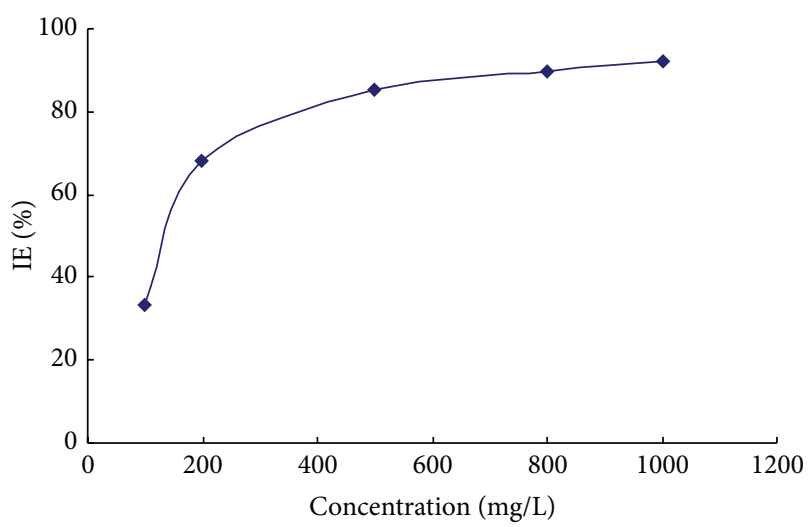

FIGURE 1: IE of PN4 for Q235A steel dissolution in 3\% $\mathrm{HCl}$ at different concentrations.

high yield. And most substituted benzaldehydes with electric withdrawing group, such as $-\mathrm{NO}_{2}$ and $-\mathrm{Cl}$, provide higher yield than that with electric donating groups, such as $-\mathrm{CH}_{3}$ and-OH. $o$-Hydroxy-benzaldehyde gives a relatively higher yield that can be due to the activation of the carbonyl group by $o-\mathrm{OH}$ group through the intramolecular hydrogen bond.

3.2. Gravimetric Measurements. Corrosion inhibition of Q235A steel by using corrosion inhibitors in 3\% $\mathrm{HCl}$ solution containing various phenyl nitrone was investigated after immersion at $333 \pm 0.5^{\circ} \mathrm{C}$ for $5 \mathrm{~h}$. Table 2 summarizes the inhibition efficiency (IE) from the weight-loss measurements. The results reveal that the structure affects the IE which varies with the substituted groups of phenyl nitrone, and PN4 displays the highest IE of $85.2 \%$ compared to PN8 with the lowest IE of $56.3 \%$. Concerning the structures, most of the molecules with electrodonating groups, such as $\mathrm{OH},-\mathrm{CH}_{3}$, and $-\mathrm{OCH}_{3}$, display relatively high inhibition efficiency, while, with two $-\mathrm{OH}$ groups, PN10 and PN11 display relatively low inhibition efficiency, which may be due to the intramolecular and/or intermolecular hydrogen bonding weakening the interaction with the steel.

The correlativity between concentration of PN4 and inhibition efficiency was shown in Figure 1. The corrosion inhibition efficiency increases sharply as the concentration rising from $100 \mathrm{mg} / \mathrm{L}$ to $500 \mathrm{gm} / \mathrm{L}$. As the concentration rising to over $500 \mathrm{mg} / \mathrm{L}$, the efficiency does not rise obviously. The highest IE, $92.3 \%$, is obtained in our study under the concentration of $1000 \mathrm{mg} / \mathrm{L}$.

3.3. Enhancement by Additives. Hexamethylenetetramine (HMTA) has a symmetric tetrahedral cage-like structure, as shown in Figure 2, whose four "corners" are nitrogen atoms and "edges" are methylene groups. The molecule behaves like 
TABLE 1: The yield, NMR, and MS of phenyl nitrone derivatives.

\begin{tabular}{|c|c|c|c|}
\hline $\mathrm{R}$ & NMR, MS & Yield (\%) & Name \\
\hline $\mathrm{H}$ & $\begin{array}{l}{ }^{1} \mathrm{H} \mathrm{NMR}\left(\mathrm{CD}_{3} \mathrm{OD}-\mathrm{CDCl}_{3}, 400 \mathrm{MHz}\right), \delta: 8.2(\mathrm{~m}, 2 \mathrm{H}), 7.4(\mathrm{~m}, 3 \mathrm{H}), 7.3 \\
\left.(\mathrm{~s}, 1 \mathrm{H}), 3.8(\mathrm{~s}, 3 \mathrm{H}) ;{ }^{13} \mathrm{C} \mathrm{NMR}_{\left(\mathrm{CD}_{3} \mathrm{OD}-\mathrm{CDCl}\right.}, 100 \mathrm{MHz}\right), \delta: 130.9, \\
129.9,129.8,129.7,128.8,128.6,128.0,51.0 ; \mathrm{MS}(\mathrm{EI}) \mathrm{m} / z: 135\left(\mathrm{M}^{+}\right)\end{array}$ & 83.4 & PN1 \\
\hline$o-\mathrm{OH}$ & 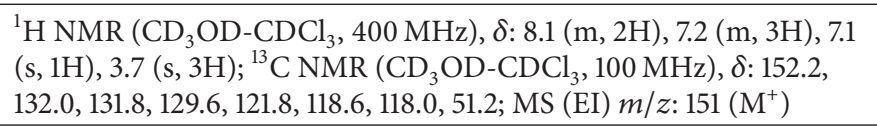 & 89.5 & PN2 \\
\hline$m-\mathrm{OH}$ & $\begin{array}{l}{ }^{1} \mathrm{H} \mathrm{NMR}\left(\mathrm{CD}_{3} \mathrm{OD}-\mathrm{CDCl}_{3}, 400 \mathrm{MHz}\right), \delta: 8.0(\mathrm{~m}, 2 \mathrm{H}), 7.2(\mathrm{~m}, 3 \mathrm{H}), 7.0 \\
\left.(\mathrm{~s}, 1 \mathrm{H}), 3.7(\mathrm{~s}, 3 \mathrm{H}) ;{ }^{13} \mathrm{C} \mathrm{NMR}_{\left(\mathrm{CD}_{3} \mathrm{OD}-\mathrm{CDCl}\right.}, 100 \mathrm{MHz}\right), \delta: 153.4, \\
132.1,131.9,129.9,122.0,117.8,117.5,51.0 ; \mathrm{MS}(\mathrm{EI}) \mathrm{m} / z: 151\left(\mathrm{M}^{+}\right)\end{array}$ & 80.0 & PN3 \\
\hline$p-\mathrm{OH}$ & 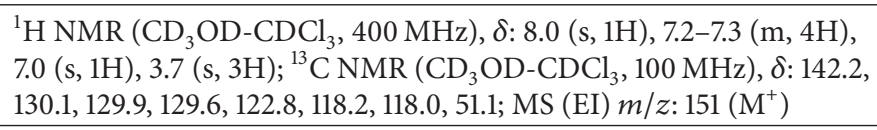 & 83.2 & PN4 \\
\hline$p-\mathrm{CH}_{3}$ & $\begin{array}{l}{ }^{1} \mathrm{H} \text { NMR }\left(\mathrm{CD}_{3} \mathrm{OD}-\mathrm{CDCl}_{3}, 400 \mathrm{MHz}\right), \delta: 8.1(\mathrm{~m}, 1 \mathrm{H}), 7.4(\mathrm{~m}, 3 \mathrm{H}), 7.3 \\
(\mathrm{~s}, 1 \mathrm{H}), 4.2(\mathrm{~s}, 3 \mathrm{H}), 3.8(\mathrm{~s}, 3 \mathrm{H}) ;{ }^{13} \mathrm{C} \mathrm{NMR}\left(\mathrm{CD}_{3} \mathrm{OD}-\mathrm{CDCl}_{3}, 100 \mathrm{MHz}\right) \text {, } \\
\delta: 138.5,129.0,128.8,128.6,127.8,126.6,126.5,51.3,24.6 ; \mathrm{MS}(\mathrm{EI}) \mathrm{m} / z: \\
149\left(\mathrm{M}^{+}\right)\end{array}$ & 79.5 & PN5 \\
\hline$o-\mathrm{Cl}$ & 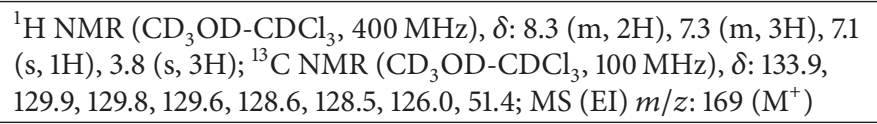 & 90.5 & PN6 \\
\hline$p-\mathrm{Cl}$ & $\begin{array}{l}{ }^{1} \mathrm{H} \mathrm{NMR}\left(\mathrm{CD}_{3} \mathrm{OD}-\mathrm{CDCl}_{3}, 400 \mathrm{MHz}\right), \delta: 8.2(\mathrm{~m}, 2 \mathrm{H}), 7.4(\mathrm{~m}, 3 \mathrm{H}), 7.3 \\
\left.(\mathrm{~s}, 1 \mathrm{H}), 3.8(\mathrm{~s}, 3 \mathrm{H}) ;{ }^{13} \mathrm{C} \mathrm{NMR}_{\left(\mathrm{CD}_{3} \mathrm{OD}-\mathrm{CDCl}\right.}, 100 \mathrm{MHz}\right), \delta: 134.2, \\
132.1,131.9,129.9,128.8,128.1,128.0,51.3 ; \mathrm{MS}(\mathrm{EI}) \mathrm{m} / z: 169\left(\mathrm{M}^{+}\right)\end{array}$ & 92.0 & PN7 \\
\hline$o-\mathrm{NO}_{2}$ & $\begin{array}{l}{ }^{1} \mathrm{H} \text { NMR }\left(\mathrm{CD}_{3} \mathrm{OD}-\mathrm{CDCl}_{3}, 400 \mathrm{MHz}\right), \delta: 9.2(\mathrm{~s}, 1 \mathrm{H}), 8.1(\mathrm{~m}, 2 \mathrm{H}), 7.8 \\
(\mathrm{~m}, 2 \mathrm{H}), 7.6(\mathrm{~m}, 1 \mathrm{H}), 3.9(\mathrm{~s}, 3 \mathrm{H}) ;{ }^{13} \mathrm{C} \mathrm{NMR}\left(\mathrm{CD}_{3} \mathrm{OD}-\mathrm{CDCl}_{3},\right. \\
100 \mathrm{MHz}), \delta: 150.1,134.9,130.2,129.7,129.6,122.4,121.8,51.4 ; \mathrm{MS}(\mathrm{EI}) \\
m / z: 180\left(\mathrm{M}^{+}\right)\end{array}$ & 96.5 & PN8 \\
\hline$p-\mathrm{NO}_{2}$ & $\begin{array}{l}{ }^{1} \mathrm{H} \text { NMR }\left(\mathrm{CD}_{3} \mathrm{OD}-\mathrm{CDCl}_{3}, 400 \mathrm{MHz}\right), \delta: 9.1(\mathrm{~s}, 1 \mathrm{H}), 8.1(\mathrm{~m}, 2 \mathrm{H}), 7.7 \\
(\mathrm{~m}, 2 \mathrm{H}), 7.6(\mathrm{~m}, 1 \mathrm{H}), 3.9(\mathrm{~s}, 3 \mathrm{H}) ;{ }^{13} \mathrm{C} \mathrm{NMR}\left(\mathrm{CD}_{3} \mathrm{OD}-\mathrm{CDCl}_{3},\right. \\
100 \mathrm{MHz}), \delta: 150.9,139.0,129.9,129.4,129.4,122.4,122.2,51.4 ; \mathrm{MS}(\mathrm{EI}) \\
m / z: 180\left(\mathrm{M}^{+}\right)\end{array}$ & 93.2 & PN9 \\
\hline $2,4-\mathrm{OH}$ & $\begin{array}{l}{ }^{1} \mathrm{H} \mathrm{NMR}\left(\mathrm{CD}_{3} \mathrm{OD}-\mathrm{CDCl}_{3}, 400 \mathrm{MHz}\right), \delta: 8.2(\mathrm{~m}, 2 \mathrm{H}), 7.3(\mathrm{~m}, 3 \mathrm{H}), 7.1 \\
(\mathrm{~s}, 1 \mathrm{H}), 3.8(\mathrm{~s}, 3 \mathrm{H}) ;{ }^{13} \mathrm{C} \mathrm{NMR}\left(\mathrm{CD}_{3} \mathrm{OD}-\mathrm{CDCl}_{3}, 100 \mathrm{MHz}\right), \delta: 160.5, \\
157.8,131.8,129.9,110.2,109.6,108.1,51.2 ; \mathrm{MS}(\mathrm{EI}) \mathrm{m} / z: 167\left(\mathrm{M}^{+}\right)\end{array}$ & 92.6 & PN10 \\
\hline $3,5-\mathrm{OH}$ & $\begin{array}{l}{ }^{1} \mathrm{H} \mathrm{NMR}\left(\mathrm{CD}_{3} \mathrm{OD}-\mathrm{CDCl}_{3}, 400 \mathrm{MHz}\right), \delta: 8.1(\mathrm{~m}, 2 \mathrm{H}), 7.2(\mathrm{~m}, 3 \mathrm{H}), 7.1 \\
(\mathrm{~s}, 1 \mathrm{H}), 3.8(\mathrm{~s}, 3 \mathrm{H}) ;{ }^{13} \mathrm{C} \mathrm{NMR}\left(\mathrm{CD}_{3} \mathrm{OD}-\mathrm{CDCl}_{3}, 100 \mathrm{MHz}\right), \delta: 159.9, \\
159.2,132.9,129.5,108.4,108.3,103.6,51.3 ; \mathrm{MS}(\mathrm{EI}) \mathrm{m} / z: 167\left(\mathrm{M}^{+}\right)\end{array}$ & 88.7 & PN11 \\
\hline
\end{tabular}

TABLE 2: Inhibition efficiency of phenyl nitrone for Q235A steel in $3 \% \mathrm{HCl}$ solution.

\begin{tabular}{lcc}
\hline Inhibitor & Concentration $(\mathrm{mg} / \mathrm{L})$ & IE $(\%)$ \\
\hline PN1 & 500 & 75.0 \\
PN2 & 500 & 67.8 \\
PN3 & 500 & 80.5 \\
PN4 & 500 & 85.2 \\
PN5 & 500 & 80.5 \\
PN6 & 500 & 66.7 \\
PN7 & 500 & 65.7 \\
PN8 & 500 & 56.3 \\
PN9 & 500 & 83.7 \\
PN10 & 500 & 65.2 \\
PN11 & 500 & 69.6 \\
\hline
\end{tabular}

an amine base, undergoing protonation and $N$-alkylation. With these features, it has been used as corrosion inhibitor. 1,4-Dihydroxy-2-butyne (BOZ), as shown in Figure 2 containing hydroxyl groups and p-electrons in triple bonds, is also used as a corrosion inhibitor in many conditions, but it was found that the inhibition efficiency is relatively low; moreover much quantity is needed to obtain high inhibition efficiency (about 1-3\%), so both are only used as additives in some combined corrosion inhibitors [14]. So HMTA and $\mathrm{BOZ}$ were investigated as synergists for the PN4, and the results were shown in Figure 3.

From Figure 3, it was found that HMTA and BOZ are not efficient inhibitors with the IE of $23.8 \%$ and $35.7 \%$, respectively, while they can enhance the IE of PN4 from $85.2 \%$ to $95.6 \%$ and $98.5 \%$, respectively. The reason should be due to the fruitful $p$-electrons of $\mathrm{N}, \mathrm{O}$ and triple bond, which 


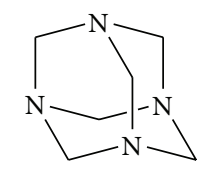

Hexamethylenetetramine

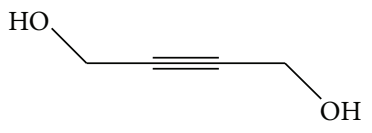

1,4-Dihydroxy-2-butyne
FIgURE 2: The structure of hexamethylenetetramine and 1,4dihydroxy-2-butyne.

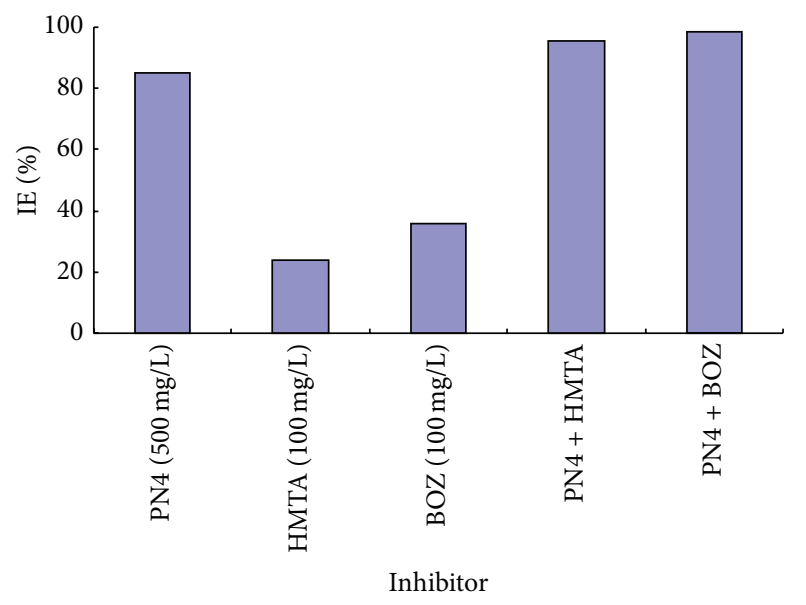

FIgUre 3: The IE of PN4 companied with HMTA or DHBY.

can form covalent bonds between the molecules and the ion surface, capture $\mathrm{H}^{+}$to release the acidity, and even link PN4 molecules as "bridges" to enhance the protective film on the ion surface.

3.4. Electrochemical Impedance Spectroscopy. The potentiodynamic polarization curves for mild steel in acid solution in the absence and presence of various concentrations of PN4 are shown in Figure 4. Extracts at different concentrations lead to different anodic, cathodic Tafel slopes, and the $E_{\text {corr }}$ values, suggesting that these compounds behave as mixed-type (anodic/cathodic) inhibitors [15]. Increasing inhibition efficiencies with increasing concentration shows that the inhibition occurs because of adsorption on the steel surface [16]. The inhibition efficiencies obtained from potentiodynamic polarization were different from those calculated from weight-loss measurements; the reason is that weight-loss method gives average corrosion rate whereas the electrochemical method gives instantaneous corrosion rates. These variations may also arise because of the different times required to form the adsorbed layer of the inhibitors on metal surface that inhibit corrosion [17].

3.5. Mechanism. It is well known that organic inhibitors establish inhibition by adsorption onto the metal surface, and the adsorption of the organic compounds can be described by two main types of interaction: physical adsorption and chemisorption that are influenced by the nature and charge of the metal, the chemical structure of the inhibitor, and the type of electrolyte. The presence of $\mathrm{N}, \mathrm{O}$, and $\mathrm{S}$ atoms and

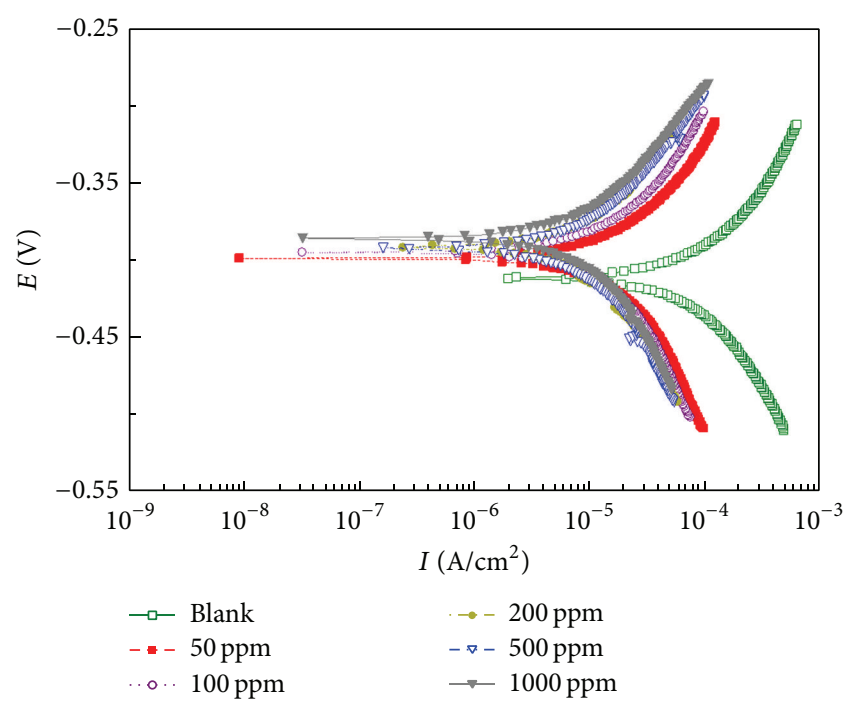

FIgURE 4: Typical polarization curves for corrosion of Q235A steel in $1 \mathrm{M} \mathrm{HCl}$ in the absence and presence of different concentrations of PN4.

conjugated double bonds in the organic structures makes the formation of $p-d$ bonds resulting from overlap of $p$-electrons to the $3 \mathrm{~d}$ vacant orbital of iron atoms, which enhances the adsorption of the inhibitors on the metal surface [18].

The steady conformation of PN4 was expressed in Figure 5, which was simulated by a minimized energy of MM2 in Chem 3D, and the p-electrons of the hydroxyl groups were colored in pink. The inhibition efficiency afforded by PN4 may be attributed to the presence of electron-rich nitrone group, phenol group, and phenyl group. The possible reaction centers are unshared electron pair of heteroatoms and $p$-electrons of phenyl group. The schematic illustration of different modes of adsorption on metal is shown in Figure 6.

3.6. Antibacterial Activity against Oilfield Microorganism. Microbiologically influenced corrosion (MIC) is metal deterioration as a result of the metabolic activity of various microorganisms. This type of corrosion applies to nonmetallic objects as well as metals. For instance, aerobic bacteria such as Acidithiobacillus thiooxidans can cause significant corrosion as they serve as a factor in biogenic sulfide corrosion. As MIC bacteria grow, consumption of the metal in the pipe occurs and sometimes tubercles are formed. Pitting is a likely effect and the walls of the pipe may be penetrated, but the flow characteristics of the pipes are degraded and the loose scale or rust can plug sprinklers and valves. MIC can be prevented through periodic mechanical cleaning, chemical treatment using biocides to prevent bacteria population, and dry storage and total drainage.

In oilfield, the MIC is mainly caused by the growth of such microorganism as sulfate reducing bacteria (SRB), iron bacteria (IB), and total general bacteria (TGB) in oil pipelines, which is considered as a major problem for water treatment in the oilfield [19]. MIC can result in different types of attack, such as pitting, crevices, dealloying, and erosion in 


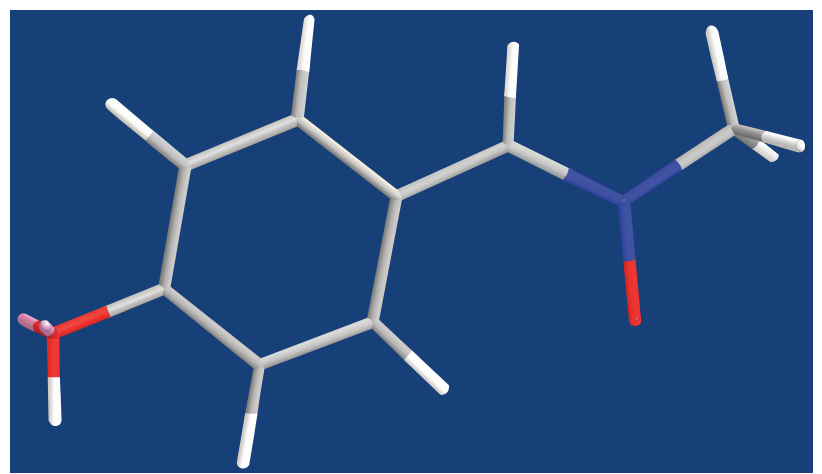

FIgURE 5: The steady conformation of PN4.

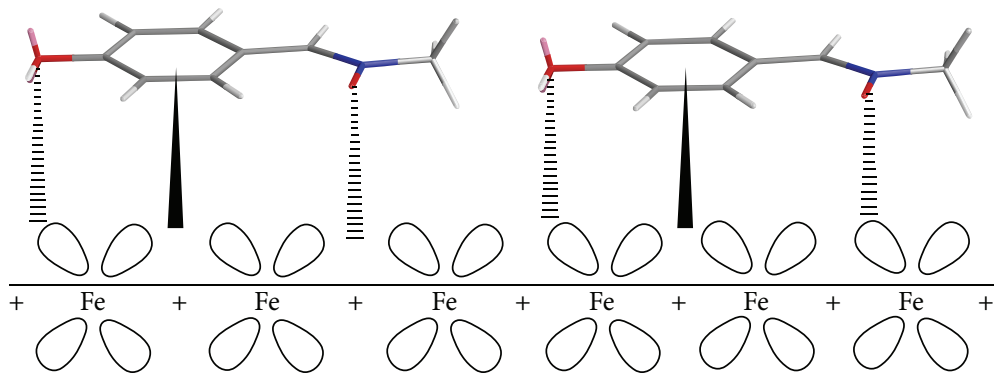

-1IIII Interaction with the $p$-electrons

Interaction with the aromatic $\pi$-electrons

FIgURE 6: The absorption of PN4 on the steel surface by coordination.

TABLE 3: The antifungal activity of PN against oilfield waterborne bacteria.

\begin{tabular}{lcccc}
\hline \multirow{2}{*}{ MGLE } & $\begin{array}{c}\text { Concentration } \\
\mathrm{mg} / \mathrm{L}\end{array}$ & \multicolumn{2}{c}{ Microbiotic concentration/mL } \\
& - & $2.5 \times 10^{4}$ & $2.5 \times 10^{4}$ & $2.5 \times 10^{4}$ \\
& 1,000 & $2.5 \times 10^{3}$ & $7.0 \times 10^{2}$ & $2.5 \times 10^{2}$ \\
PN1 & 1,000 & $2.5 \times 10^{4}$ & $2.5 \times 10^{1}$ & $2.5 \times 10^{2}$ \\
PN2 & 1,000 & $7.0 \times 10^{3}$ & $1.1 \times 10^{1}$ & $2.5 \times 10^{2}$ \\
PN3 & 1,000 & $0.9 \times 10^{1}$ & $2.5 \times 10^{0}$ & $2.5 \times 10^{0}$ \\
PN4 & 1,000 & $0.9 \times 10^{1}$ & $1.1 \times 10^{0}$ & $2.5 \times 10^{1}$ \\
PN5 & 1,000 & $0.9 \times 10^{2}$ & $7.0 \times 10^{0}$ & $1.1 \times 10^{2}$ \\
PN6 & 1,000 & $2.5 \times 10^{4}$ & $2.5 \times 10^{3}$ & $2.5 \times 10^{1}$ \\
PN7 & 1,000 & $0.9 \times 10^{1}$ & $2.5 \times 10^{0}$ & $2.5 \times 10^{1}$ \\
PN8 & 1,000 & $2.5 \times 10^{2}$ & $0.9 \times 10^{0}$ & $0 \times 10^{0}$ \\
PN9 & 1,000 & $2.5 \times 10^{1}$ & $7.0 \times 10^{1}$ & $2.5 \times 10^{2}$ \\
PN10 & 1,000 & $0.9 \times 10^{4}$ & $2.5 \times 10^{0}$ & $2.5 \times 10^{0}$ \\
PN11 & & & &
\end{tabular}

pipelines [20]. In addition, microbial degradation of crude oil can lead to increased acidity in the oil phase, and the high-acid-contained oil is a problem concerning corrosion of pipelines. Even more serious, the interaction of IB, SRB, and TGB can accelerate the corrosion rate; in other words, the corrosion in the mixture of IB, SRB, and TGB was more serious than in a single microbial system. Based on this case, different treatment systems to inhibit corrosion should be considered, among which using bactericide has received the greatest acceptance. Currently, oxidizer, aldehyde, quaternary ammonium salt, and heterocycle compounds, such as $\mathrm{Cl}_{2}$, $\mathrm{ClO}_{2}$, formaldehyde, pentane-1,5-dial, trichloroisocyanuric acid (TCCA), Schiff base, and some natural products, have been used as bactericides [21-23], but the toxicity and oxidation tests have been conducted on a limited selection.

Since the researches have shown nitrone derivatives to be antibacterial active [2-5], the PNs are anticipated to be bactericides for oilfield microorganism. The inhibition of PNs against oilfield microorganism was investigated under the concentrations of $1,000 \mathrm{mg} / \mathrm{L}$, and the results are summarized in Table 3. The results show that the some of the PNs are active against the three microorganisms. For TGB, PN4, PN5, PN6, $\mathrm{PN} 8$, and $\mathrm{PN} 10$ are very active, for IB almost all $\mathrm{PNs}$ are active except PN1 and PN7, and for SRB all PNs display inhibitions, in which PN4, PN9, and PN11 are the top active ones.

\section{Conclusion}

In this work, a series of phenyl nitrone derivatives (PN) was synthesized and characterized. Then the corrosion inhibition efficiency and the mechanism of these nitrone derivatives were investigated. The results indicate that several compounds show high IE of over $80 \%$ in $3 \% \mathrm{HCl}$. Accompanied with HMTA or BOZ, the IEs greatly increase, and the 
highest efficiency of $98.5 \%$ was obtained by using PN4 + BOZ. Investigation of the antibacterial activity against oilfield microorganism shows that the nitrone derivatives can inhibit SRB, IB, and TGB with moderate to high efficiency under $1,000 \mathrm{mg} / \mathrm{L}$, which makes them potential to be used as bifunctional oilfield chemicals.

\section{Conflict of Interests}

The authors declare that there is no conflict of interests regarding the publication of this paper.

\section{Acknowledgments}

This work was financially supported by the grants from National Science Foundation of China (21376189), Technological Plan Projects of Shaanxi Province of China (2012KJXX-40), and Scientific Research Plan Projects of Shaanxi Education Department (2013JK0647).

\section{References}

[1] A. Adwa and W. H. Pearson, Synthetic Application of 1,3,-Dipolar Cycloaddition Chemistry toward Heterocycles and Natural Products, Wiley, Hoboken, NJ, USA, 2003.

[2] R. A. Floyd, R. D. Kopke, C.-H. Choi, S. B. Foster, S. Doblas, and R. A. Towner, "Nitrones as therapeutics," Free Radical Biology and Medicine, vol. 45, no. 10, pp. 1361-1374, 2008.

[3] D. P. Xu, K. Zhang, Z. J. Zhang et al., "A novel tetramethylpyrazine bis-nitrone (TN-2) protects against 6-hydroxyldopamine-induced neurotoxicity via modulation of the NF$\kappa \mathrm{B}$ and the $\mathrm{PKC} \alpha / \mathrm{PI} 3-\mathrm{K} / \mathrm{Akt}$ pathways," Neurochemistry International, vol. 78, pp. 76-85, 2014.

[4] R. A. Floyd, H. C. C. F. Neto, G. A. Zimmerman, K. Hensley, and R. A. Towner, "Nitrone-based therapeutics for neurodegenerative diseases: their use alone or in combination with lanthionines," Free Radical Biology and Medicine, vol. 62, pp. 145-156, 2013.

[5] P. Sambasiva Rao, C. Kurumurthy, B. Veeraswamy et al., "Synthesis of novel 1,2,3-triazole substituted-N-alkyl/aryl nitrone derivatives, their anti-inflammatory and anticancer activity," European Journal of Medicinal Chemistry, vol. 80, pp. 184-191, 2014.

[6] J. Yang, "Recent developments in nitrone chemistry: some novel transformations," Synlett, vol. 23, no. 16, pp. 2293-2297, 2012.

[7] N. R. Sheela, S. Sampathkrishnan, M. T. Kumar, and S. Muthu, "Quantum mechanical study of the structure and spectroscopic, first order hyperpolarizability, Fukui function, NBO, normal coordinate analysis of Phenyl-N-(4-Methyl Phenyl) Nitrone," Spectrochimica Acta Part A: Molecular and Biomolecular Spectroscopy, vol. 112, pp. 62-77, 2013.

[8] Y.-L. Yang, Y. Wei, Q. Xu, and M. Shi, "Nitrogen-containing Lewis bases catalyzed highly regio- and stereoselective reactions of allenyl acetates with isatin-derived oximes," Tetrahedron, vol. 69, no. 17, pp. 3593-3607, 2013.

[9] D. Basavaiah, S. S. Badsara, and G. Veeraraghavaiah, "BaylisHillman carbonates in organic synthesis: a convenient one-pot strategy for nitrone-spiro-oxindole frameworks," Tetrahedron, vol. 69, no. 37, pp. 7995-8001, 2013.
[10] L. Vretik and H. Ritter, "1,3-dipolar cycloaddition in polymer synthesis. 1. Polyadducts with flexible spacers derived from bis(N-methylnitrone)s and bis( $N$-phenylmaleimide)s," Macromolecules, vol. 36, no. 17, pp. 6340-6345, 2003.

[11] M. Thirumalaikumar and S. Jegannathan, "Inhibition effects of nitrones on the corrosion of mild steel in organic acid media," Portugaliae Electrochimica Acta, vol. 29, no. 1, pp. 1-8, 2011.

[12] I. S. Young and M. A. Kerr, "A homo [3+2] dipolar cycloaddition: the reaction of nitrones with cyclopropanes," Angewandte Chemie International Edition, vol. 42, no. 26, pp. 3023-3026, 2003.

[13] P. A. S. Smith and S. E. Gloyer, "Equilibrium in the behrend rearrangement of nitrones," Journal of Organic Chemistry, vol. 40, no. 17, pp. 2504-2508, 1975.

[14] F. H. Xie and H. Xuan, "Synthesis and inhibiting performance of an imidazolinyl-quaternary ammonium salts inhibitor with multi-activated sites," Chinese Journal of Applied Chemistry, vol. 28, no. 1, pp. 94-100, 2011.

[15] S. Issaadi, T. Douadi, A. Zouaoui, S. Chafaa, M. A. Khan, and G. Bouet, "Novel thiophene symmetrical Schiff base compounds as corrosion inhibitor for mild steel in acidic media," Corrosion Science, vol. 53, no. 4, pp. 1484-1488, 2011.

[16] E. Bayol, K. Kayakirilmaz, and M. Erbil, "The inhibitive effect of hexamethylenetetramine on the acid corrosion of steel," Materials Chemistry and Physics, vol. 104, no. 1, pp. 74-82, 2007.

[17] S. S. Abd El Rehim, M. A. M. Ibrahim, and K. F. Khaled, "Corrosion inhibition and adsorption behaviour of 4-aminoantipyrine on carbon steel in $\mathrm{H}_{2} \mathrm{SO}_{4}$," Corrosion Prevention and Control, vol. 46, no. 6, p. 157, 1999.

[18] K. C. Emregül and M. Hayvali, "Studies on the effect of a newly synthesized Schiff base compound from phenazone and vanillin on the corrosion of steel in $2 \mathrm{M} \mathrm{HCl}$," Corrosion Science, vol. 48, no. 4, pp. 797-812, 2006.

[19] F. Kajiyama and K. Okamura, "Evaluating cathodic protection reliability on steel pipe in microbially active soils," Corrosion, vol. 55, no. 1, pp. 74-80, 1999.

[20] P. Rupi, "Assessment and control of mic in the oil industry in the 20th century," in Proceedings of the Corrosion, NACE-00390, Orlando, Fla, USA, March 2000.

[21] H. T. Liu, L. Huang, T. Li, Y. L. Gu, and J. Chin, "Application and progress in bactericide of sulfate reducing bacteria," Journal of Chinese Society for Corrosion and Protection, vol. 29, no. 2, pp. 154-160, 2009.

[22] G. Chen, H. J. Su, M. Zhang et al., "New bactericide derived from isatin for treating oilfield reinjection water," Chemistry Central Journal, vol. 6, no. 1, p. 90, 2012.

[23] G. Chen, M. Zhang, J. R. Zhao, R. Zhou, Z. C. Meng, and J. Zhang, "Investigation of Ginkgo biloba leave extracts as corrosion and oil field microorganism inhibitors," Chemistry Central Journal, vol. 7, article 83, 2013. 

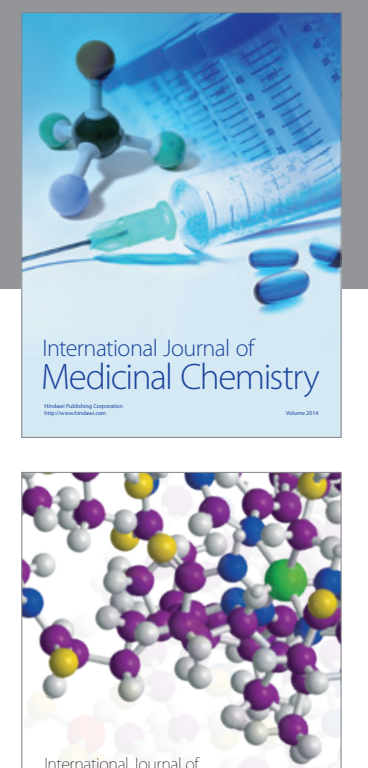

\section{Carbohydrate} Chemistry

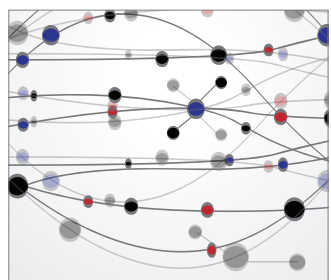

The Scientific World Journal
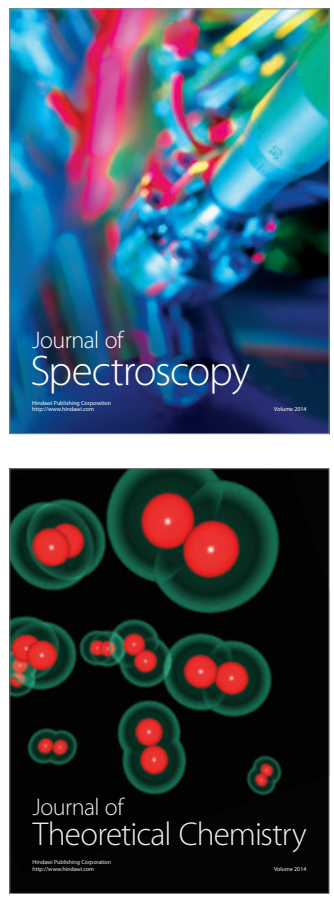
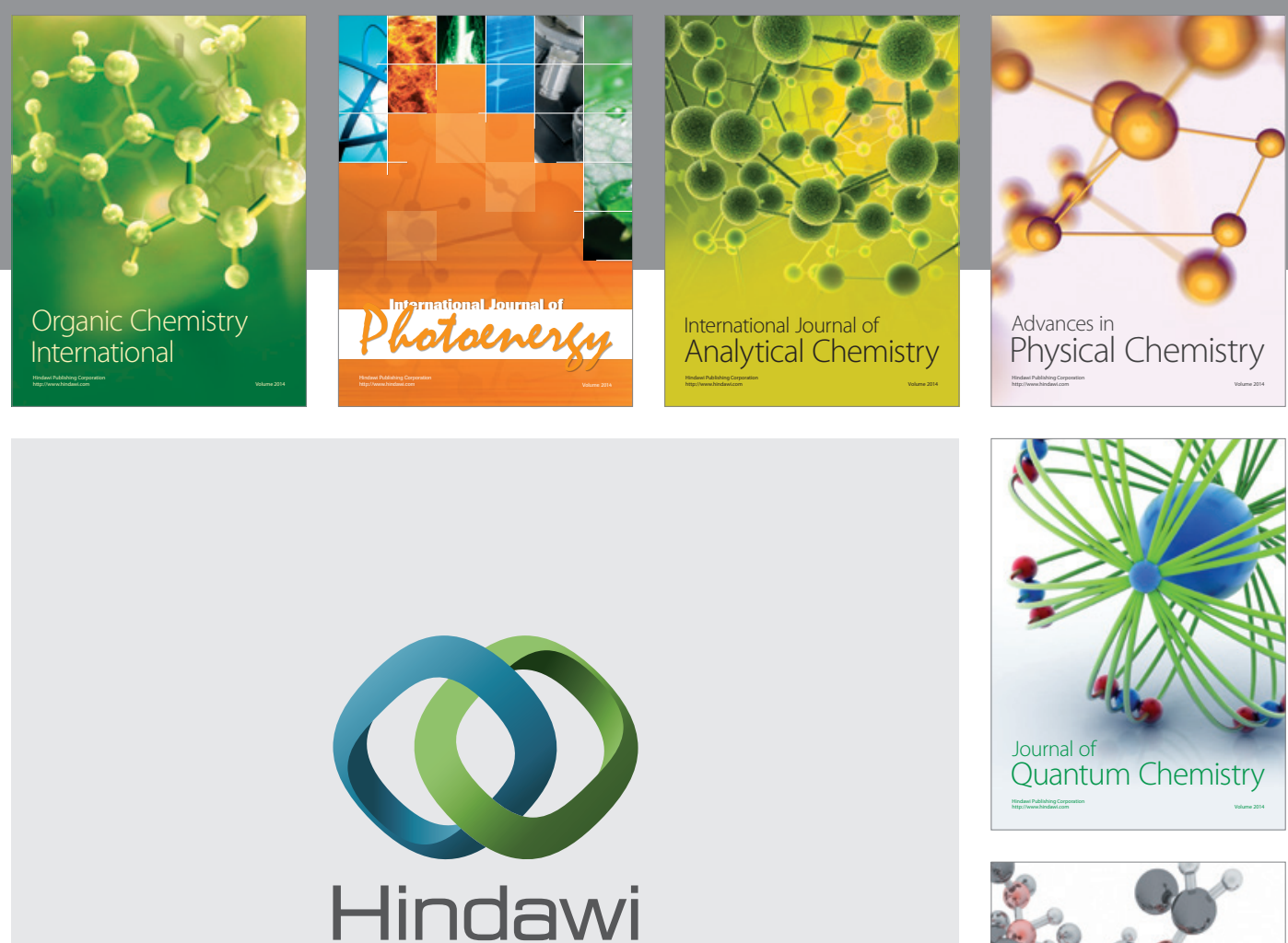

Submit your manuscripts at

http://www.hindawi.com

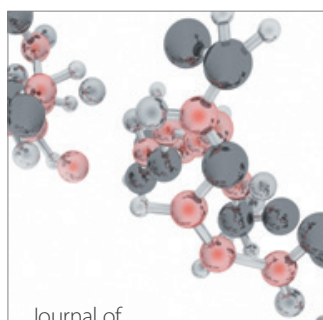

Analytical Methods

in Chemistry

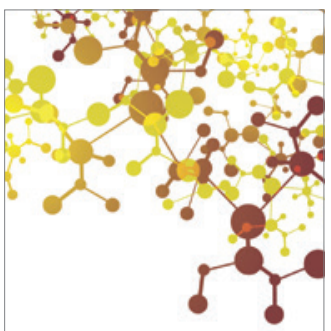

Journal of

Applied Chemistry

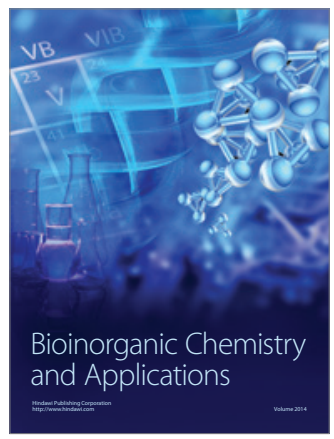

Inorganic Chemistry
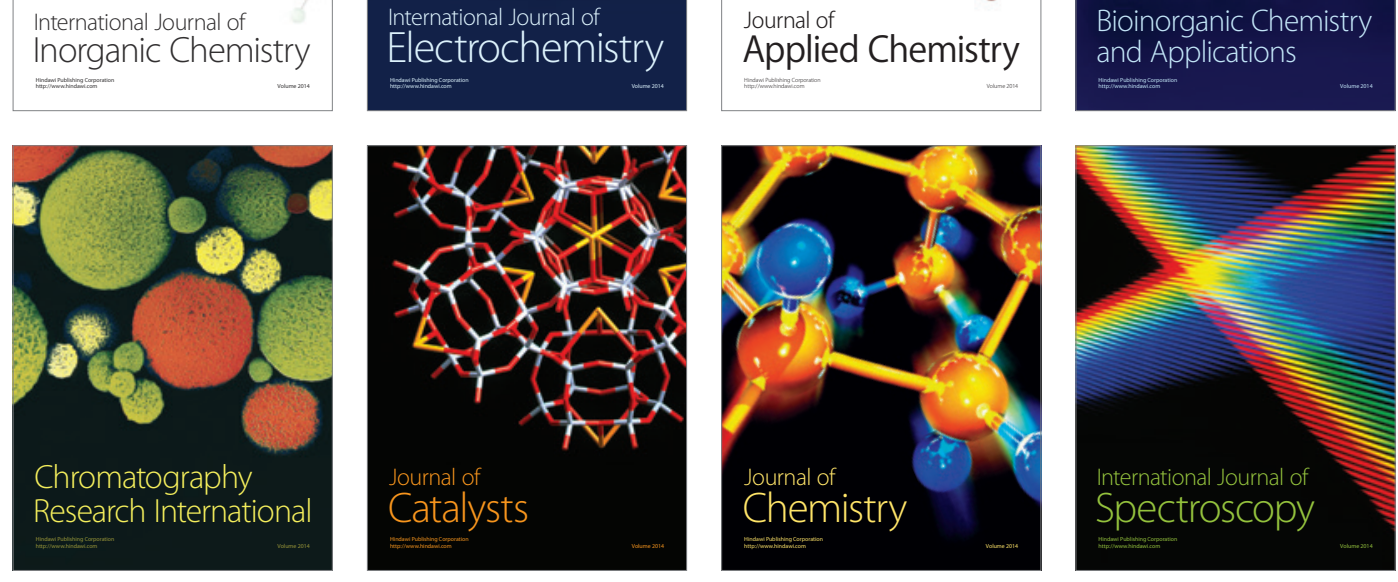